\title{
Analysis of Yield Gap in Kharif Onion Variety Agri found Dark Red under Demonstrations in Bihar, Rajasthan and Gujarat States of India
}

\author{
J. K. Tiwari ${ }^{1 *}$, Divya ${ }^{2}$, H. M. Singh ${ }^{1}$ and Garima Tiwari ${ }^{3}$ \\ ${ }^{1}$ National Horticultural Research and Development Foundation, Patna (Bihar), India \\ ${ }^{2}$ Sam Higginbottom University of Agriculture, Technology and Science, \\ Prayagraj (UP), India \\ ${ }^{3}$ Integral Universities - Luck now (UP), India \\ *Corresponding author
}

\section{A B S T R A C T}

\section{Keywords}

Technology dissemination; Demonstration, Technology gap; Extension gap; Technology index; Adoption index, Onion;

\section{Article Info}

Accepted: 22 February 2020 Available Online: 10 March 2020
Demonstrations are the one of the most important tool for transfer of technology at grass root level that directly impacts the spread of technology. Onion is grown in kharif, late kharif and Rabi seasons in India, major onion grown in Rabi season all over India, but it's cultivated on upland in kharif/ late kharif all over India. Even though its productivity recorded is low due to lacking in knowledge of scientific production technology and high yielding variety suitable to soil and climate. In order to increase the productivity of kharif onion with adoption of improved technology, 80 no's of demonstration in 20 hectare on onion variety Agrifound Dark Red (ADR) were conducted during 2014-15 by National Horticultural Research and Development Foundation, in different locations of three states viz Bihar, Rajasthan and Gujarat state through TDTD (Technology Dissemination through Demonstration) under National Horticulture Mission at selected farmers' fields. From the conducted demonstrations, it was revealed that, an average increased yield of onion crop 15.82\% was achieved with average technology gap of $42.92 \mathrm{q} / \mathrm{ha}$ of onion bulb production. Also reduce technology index of $17.17 \%$ was noticed during the year. The onion produced higher yield (average $207.08 \mathrm{q} / \mathrm{ha}$ ) on demonstrations plot over locally available variety (average $178.80 \mathrm{q} / \mathrm{ha}$ ) on control plot but remain behind to touch its potential yield ( $250 \mathrm{q} / \mathrm{ha})$. The gross returns, net returns and B: C Ratio was recorded higher in Gujarat state followed by Rajasthan and Bihar on demonstration plot compared to control. Further the technology index was lower and its adoption index were also highest in demonstration plot of Gujarat and technology index was highest its adoption index were lowest in demonstration plot of Bihar state as well as control plot. The monetary returns were found to be influenced by crop yield and prevailing market prices of the produce. During all the years of demonstration, higher monetary returns with benefit: cost ration were obtained from the technology demonstrated plots as compared to farmers control plot. An increased average net maximum monetary return of Rs 471820.00 with B:C ratio 5.78 was obtained in demonstrations plot of Gujarat while lowest in Bihar Rs 333200.00 and B: C ratio 5.12 was obtained in the demonstrated technology over control plot with average net monetary returns Rs 218500.00 and B: C 3.87. The higher returns was due to higher bulbs yields as well as higher market price with sorting/grading of bulbs obtained in the demonstration technology over control plots. Obtained maximum onion bulb yield with higher monetary returns, B:C ratio, higher adoption index, reduction in technology index $\%$ \& extension gap Qt1/ ha in Gujarat State, whereas Obtained minimum onion bulb yield with lower monetary returns with B:C ratio, lower adoption index, maximum technology index \% \& maximum extension gap Qtl/ ha in Bihar state. 


\section{Introduction}

India has a largest area under onion crop. Yield wise it is second in the world after China. In India, total area under vegetable cultivation is 6.24 million hectares and total production 98.5 million tonnes. The productivity of onion is much low in India than the world average (Pandey, 2000: Lawande, 2005). The production and productivity of onion is varying in state to state specially in Bihar are low in compared to Gujarat, Maharashtra and other onion growing states (Gupta and Singh,2010). That is due to lack of knowledge to farmers regarding suitable seasons, varieties of different seasons, climate, Soil and improved cultivation techniques are the main reasons. Unawareness of the characteristic of the varieties, seasonality's and adoption of proper package of practices are also the reasons responsible for limiting the production and productivity of onion directly or indirectly (Pandey and Bhondey, 2002). But insufficient and improper extension activities results in non-adoption of improved packages developed at research Institutes. Further the replacement ratio of traditional varieties with improved varieties and non availability of sufficient quantity of quality seeds of improved variety in a time, are the major constrains in onion cultivation. The major onion growing states are Maharashtra (30\%), Madhya Pradesh (15\%), Karnataka (11\%), Gujarat (10\%) and Bihar (7\%), Andhra Pradesh (5\%), Rajasthan (4\%), Haryana (3\%) and others (15\%) (Indian Horticulture, Database 2015). Onion (Allium cepa L.) an important bulb vegetable crop belonging to the family Aliaceae is valued for its bulbs having characteristics odour, flavour and pungency. Green leaves of onion and bulbs are used for fresh consumption as greens in salad (Lannoy, 2001) and also cooked as raw material in many ways in curries, fried, boiled, baked and used in making soups, pickles etc. (Strub and Emmet, 1992). Hence, there is a need to maximize the onion cultivation area with the introduction of improved cultivation technologies for onion crop. In the survey made to compile production level of onion crop at grass root level, it comes to know that, among all the production factors variety contribute a major share in the crop production. Hence, crop demonstrations on integrated crop management in onion with var. Agrifound Dark Red were conducted in 2014-15 by National Horticultural Research and Development Foundation, in different locations of three states viz Bihar, Rajasthan and Gujarat state through TDTD (Technology Dissemination through Demonstration) under National Horticulture Mission at selected farmers' fields.

\section{Materials and Methods}

A large scale of 80 nos demonstration of Kharif onion variety Agrifound Dark Red (ADR) arranged by National Horticultural Research and Development Foundation (NHRDF) in three states of different locations of the country through TDTD (technology dissemination through demonstration) under MIDH during 2014-15. Each demonstration was comprised of 0.25 ha local variety was grown for comparison. Materials for the present study with respect of TDTDs adoption and farmer's practices were given in below. In case of local control plots, existing practices being used by farmers were followed. In general soils of the area under study were sandy loam, clay to loamy sand and medium to low in fertility status. The TDTD was conducted to study the gaps between the potential yield and demonstration yield, extension gap and technology index. In the present evaluation study, the data on output of kharif onion cultivation were collected from TDTD plots, besides the data on local practices commonly adopted by the 
farmers of this region were also collected with farmers interview and was calculated .The data on production cost, input used, monitory return, gap and adoption index were collected and analyzed for the economic feasibility of the recommended technology (Eswarprasad, et. al., (1983) and were calculated by using following formula as suggested by samui et. al.,(2000).

Technology gap $=$ Potential yield Demonstration yield

Extension gap $=$ Demonstration yield - yield under existing practice

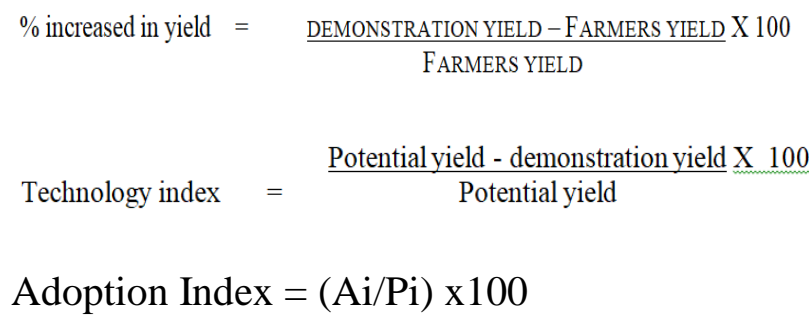

Adoption was operationally defined as the degree of actual use of recommended cultivation practices by onion growers. In demonstration plots, a few critical inputs in the farm of quality seed, Tricoderma viridi, bio fertilizers, Agro-chemical, etc. were provided and nonmonetary inputs like timely sowing in raised bed low tunnel, poly house, transplanting on beds were also performed in all states. Traditional practices were maintained in case of local control.

The farmers involved in demonstration were facilitated by NHRDF experts/ scientist in performing field operations like nursery sowing, transplanting, irrigation, spraying, weeding, harvesting etc. during the course of training and visit. The technologies demonstrated are mentioned in following:-

Adoption of recommended cultivation practices for onion production.
Land preparation - Ploughing, harrowing Variety - Agrifound Dark Red (ADR) it is Improved variety and local variety/ own seed use etc.

Rising of seedlings - Rising of onion seedlings in the month of June, July, and August on flat bed.

Seed rate $-9-10 \mathrm{~kg} / \mathrm{ha}$.

Transplanting of seedlings - Seedling with about 45-50 days with height of 10-15 $\mathrm{cm}$, Small size $(4 \times 3 \mathrm{~m})$ bed with ridges in $15 \mathrm{~cm}$ distance. Spacing- Row to row $-15 \mathrm{~cm}$. plant to plant $10 \mathrm{~cm}$ or spacing $10 \times 10 \mathrm{~cm}$.

Intercultural operation; - Spraying of Pendimethalin@1.0 kg/ha with one hand weeding at 45 DAT. Application of recommended dose of fertilizer N: P: K @ 100:50:50 kg/ha through DAP \& MOP as basal doses and urea two top dressing on 30 and 45 DAT.

Plant protection- Trichoderma viride application in nursery sowing and regent $2.5 \mathrm{ml} /$ litre of water for thrips control carbendazine $2.5 \mathrm{gm} /$ litre of water for stemphyllium blight and purple blotch disease along with sticker's@0.06\% first spray after 30 DAP and second are after 45 DAP.

Pest and disease management- Adoption of Integrated pest and disease management as recommended in PoP.

Harvesting- Neck fall stage, yellowing of leaves, bulb stage, 180 days from seed sowing on main field.

Curing - 10-15 days for curing.

Sorting / Grading

\section{Results and Discussion}

The yield data regarding bulb yield of onion crop, technology gap, extension gap, technology index, adoption index and C: B ratio for the demonstration of onion crop during 2014-15 were recorded and reported in table-1-2 and discussion under following parameters. 


\section{Crop yield}

The data regarding bulb yield of onion crop presented in table 1 , it was revealed that, the increase onion yield over the control were noticed during all the state of demonstration. The maximum average onion yield ( 237.75 $\mathrm{qtl} / \mathrm{ha}$ ) was recorded in demonstration plot of Gujarat state with $19.23 \%$ average increased yield over the control plot, whereas in minimum onion yield ( $147.50 \mathrm{qt} / \mathrm{ha})$ was recorded in demonstration plot of Bihar state with $16.95 \%$ average increased yield over the control plot.

\section{Technology Gap}

As per data of table 1 the average technology gap of $42.92 \mathrm{q} / \mathrm{ha}$ was recorded i.e. yield gap between demonstrated technology and potential yield that needs to be minimized with the conduction of demonstrations. The variation in technology gap during the demonstration year may be due to varied soil fertility, climatic condition of the area and management practices implemented by the farmers. Hence more location specific recommendations and precise use of technology in the field are necessary to bridge the technology gap as supported by Singh et al., 2011. The minimum technology gap $(12.25 \mathrm{Q} / \mathrm{ha})$ was recorded in demonstration plot of Gujarat state followed by (39.00 Q/ha) in Rajasthan state, whereas maximum technology gap $(77.50 \mathrm{Q} / \mathrm{ha})$ was recorded in demonstration plot of Bihar state.

\section{Extension Gap}

The average extension gap (28.28 q/ha) between demonstration technology and control plot was mostly due to the use of lacking in adoption of high yielding variety and use of improved production technology. The results are in conformity with the findings of Teggelli et al., 2015, who stated the progressive use of improved crop production technologies with high yielding variety, will subsequently change this alarming trend of galloping extension gap. It directed to educate and emphasised the farmers for the adoption of demonstrated technologies so as to bridge the extension gap by planning and implementation of technologies through various means of extension. The results are in agreement with the research worker Mukharjee, 2003, that location based problem identification and thereby specific interventions may be great implications in the enhancement of crop productivity. The extension gap maximum $(38.35 \mathrm{Q} / \mathrm{ha})$ in Gujarat followed by $(25.00 \mathrm{Q} / \mathrm{ha})$ in Bihar and ( $21.50 \mathrm{Q} / \mathrm{ha})$ in Rajasthan state was recorded.

Table.1 Different parameters for adoption of agricultural technologies

\begin{tabular}{|l|l|}
\hline \multicolumn{1}{|c|}{ Parameter } & \multicolumn{1}{|c|}{ Identification } \\
\hline Percentage of gross cropped area under improved seeds & Seed \\
Percentage of gross cropped area applied fertilizers & Fertilizers \\
Percentage of gross cropped area applied pesticides & Pest \\
Percentage of gross cropped area applied weedicides & Weed \\
Percentage of gross cropped area tilled by tractors & Tract \\
Percentage of gross cropped area applied sorting /grading & \\
\hline Note: All parameters are assumed to carry equal weight & \\
\hline
\end{tabular}


Table.2 Productivity, technology gap, extension gap and technology index of onion crop under TDTD during 2014-15

\begin{tabular}{|c|c|c|c|c|c|c|c|c|c|c|c|c|c|c|}
\hline \multirow[t]{2}{*}{ S.N. } & \multirow[t]{2}{*}{ State } & \multirow{2}{*}{$\begin{array}{l}\text { Area } \\
\text { (ha) }\end{array}$} & \multirow{2}{*}{$\begin{array}{l}\text { No. of } \\
\text { farmers }\end{array}$} & \multicolumn{2}{|c|}{ Yield (Q/ha) } & \multirow{2}{*}{$\begin{array}{l}\% \\
\text { increase } \\
\text { over } \\
\text { control }\end{array}$} & \multirow{2}{*}{$\begin{array}{l}\text { Technol } \\
\text { ogy gap } \\
(\mathrm{Q} / \mathrm{ha})\end{array}$} & \multirow{2}{*}{$\begin{array}{l}\text { Extensi } \\
\text { on gap } \\
\text { (Q/ha) }\end{array}$} & \multirow{2}{*}{$\begin{array}{l}\text { Techn } \\
\text { ology } \\
\text { index } \\
(\%)\end{array}$} & \multicolumn{2}{|c|}{$\begin{array}{l}\text { Adoption score } \\
\text { by respondent } \\
(\mathrm{AI})\end{array}$} & \multirow{2}{*}{$\begin{array}{l}\text { Possible } \\
\text { score } \\
(\mathrm{PI})\end{array}$} & \multicolumn{2}{|c|}{ Adoption index } \\
\hline & & & & $\begin{array}{c}\text { Demons } \\
\text { tration }\end{array}$ & Control & & & & & Demo & Control & & Demo & Control \\
\hline 1 & Rajasthan & 5 & 20 & 211.00 & 189.50 & 11.35 & 39.00 & 21.50 & 15.60 & 5 & 3 & 7 & 71.43 & 42.86 \\
\hline 2 & Gujarat & 10 & 40 & 237.75 & 199.40 & 19.23 & 12.25 & 38.35 & 4.90 & 6 & 3 & 7 & 85.71 & 42.85 \\
\hline \multirow[t]{2}{*}{3} & Bihar & 5 & 20 & 172.50 & 147.50 & 16.95 & 77.50 & 25.00 & 31.00 & 4 & 2 & 7 & 57.14 & 28.57 \\
\hline & Average & 20 & 80 & 207.08 & 178.80 & 15.82 & 42.92 & 28.28 & 17.17 & 5 & 2.67 & 7 & 71.43 & 38.14 \\
\hline
\end{tabular}

*Potential Yield (Quintal / ha) is 250/ha

Table.3 Cost and income return ratio obtained during 2014-15

\begin{tabular}{|l|c|c|c|c|c|c|c|c|}
\hline \multirow{2}{*}{ State } & \multicolumn{2}{|l|}{ Cost of production (Rs/ha) } & \multicolumn{2}{l|}{ Gross return(Rs/ha) } & \multicolumn{2}{l|}{ Net return(Rs/ha) } & \multicolumn{2}{l|}{ C: B ratio } \\
\cline { 2 - 10 } & Demonstration & Control & Demonstration & Control & Demonstration & Control & Demonstration & Control \\
\hline Rajasthan & 93250.00 & 84105.00 & 506400.00 & 379000.00 & 413150.00 & 294895.00 & 5.43 & 4.50 \\
\hline Gujarat & 98780.00 & 95890.00 & 570600.00 & 398800.00 & 471820.00 & 302910.00 & 5.78 \\
\hline Bihar & 80800.00 & 76500.00 & 414000.00 & 295000.00 & 333200.00 & 218500.00 & 5.12 \\
\hline
\end{tabular}

**@ Rs 24000/- per quintal sorted / graded onion \& Rs 2000/- un sorted / graded onion market rate 


\section{Technology Index}

The average technology index value (17.17\%), might be due to précised use of demonstrated technology in the field and suitable climatic conditions during the demonstration period. As technology index denotes the gap between technology generated at research farm and farmer's field, lower the technology index more feasible will be the technology (Jeengar et al., 2006 and Hiremath and Nagraju, 2010, Sagar and Chandra, 2004). The lowest technology index $\%$ (4.90) in Gujarat followed by $15.60 \%$ Rajasthan and $31.00 \%$ in Bihar was recorded.

\section{Cost Benefit Ratio}

The data obtained regarding cost benefit ratio for the demonstration technology was presented in table-2. It is revealed that monetary returns were directly influenced by the market price of onion bulbs and cost of production during the year of the demonstrations. During all the states of demonstrations, the increased gross monetary returns, net monetary returns and benefit; Cost ratio were obtained in the demonstrated technology over control plots. Shown in table2 that the higher net monetary returns of Rs 5 , $70,600.00$ and B: C ratio 5.78 was obtained in the demonstrated technology over control plot with net monetary returns Rs 398800.00 and B: C 4.16 in Gujarat state.

The higher returns was due to higher bulbs yields as well as higher market price with sorting/grading of bulbs obtained in the demonstration technology over control plots. These findings are in confirmation with the findings of Hiremath and Nagraju 2010, Tandel 2011, Hiremath and Hilli, 2012. Whereas lowest returns obtained 3,33,200.00 and $\mathrm{B}: \mathrm{C}$ ratio 5.12 was obtained in the demonstrated technology over control plot with net monetary returns Rs 2,18,500.00 and $\mathrm{B}: \mathrm{C}$ ratio 3.87 in Bihar .

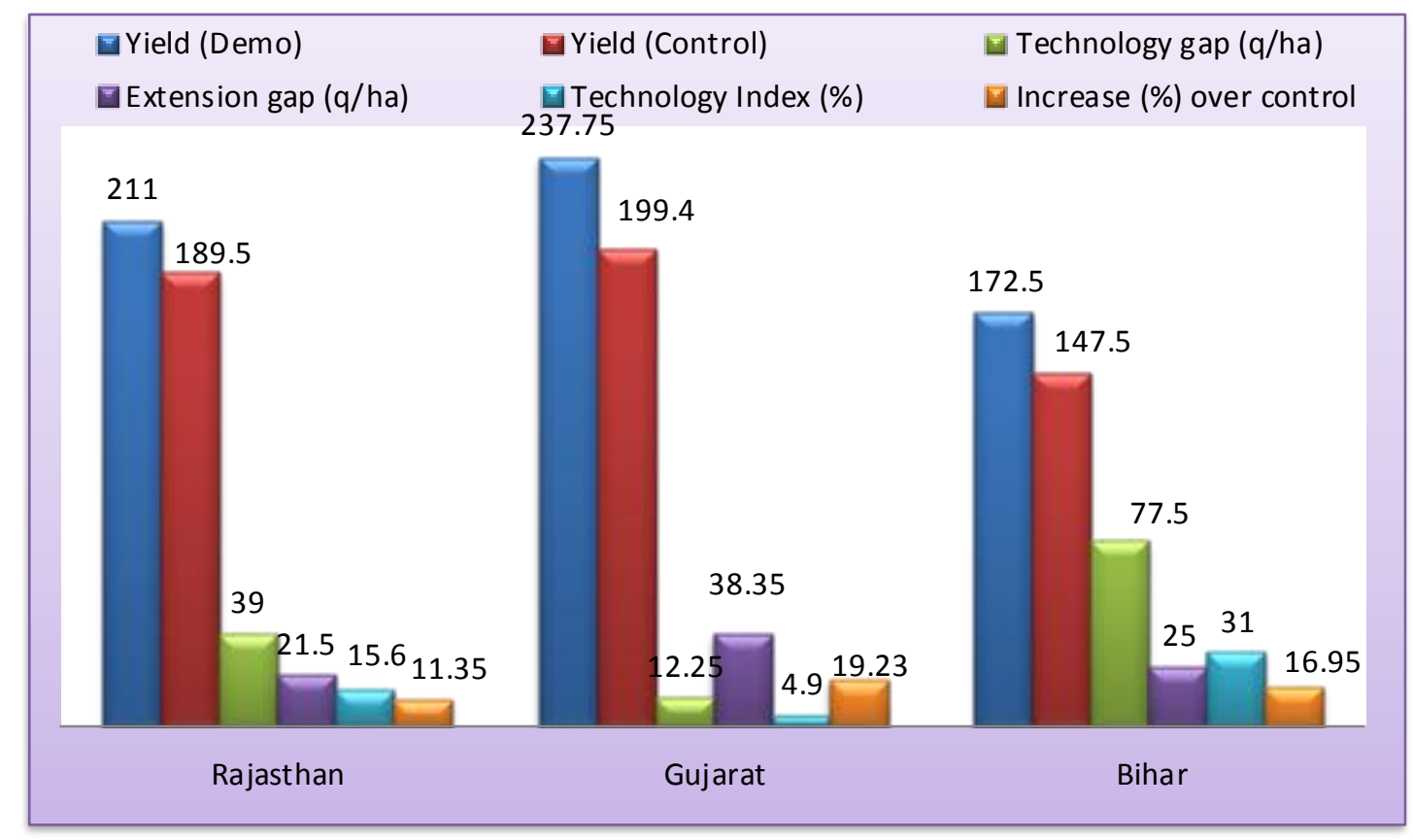

Fig.1 Onion Yield of demonstration (q/ha), control (q/ha), technology gap (q/ha), extension gap (q/ha), technology index (\%) and percentage increase over control under TDTD during 2014-15 


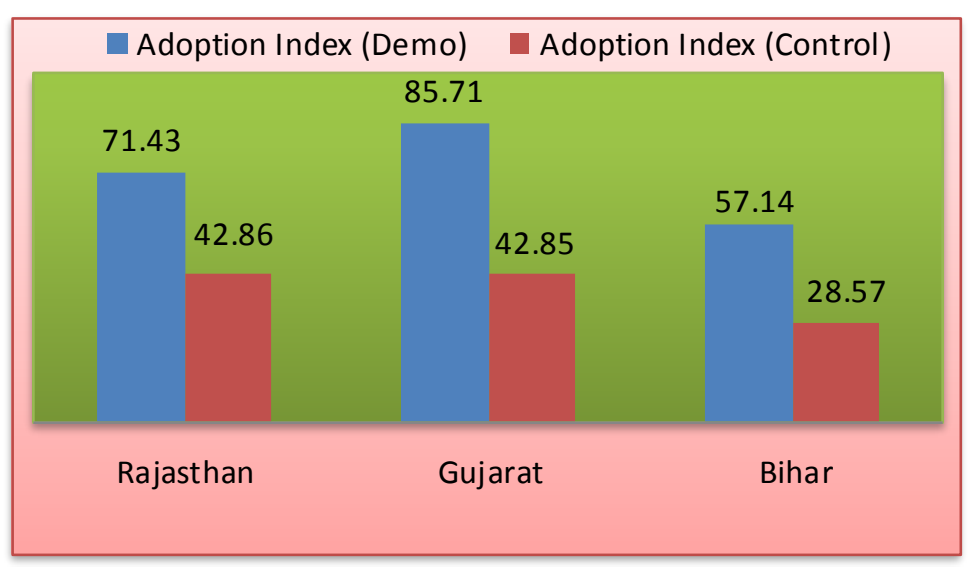

Fig.2 Adoption index of demonstration \& control under TDTD during 2014-15

\section{Adoption index}

The adoption index was higher in Gujarat compared to Bihar and Rajasthan that is due to awareness of farmer's as well as soil, climatic conditions and adoption of improved cultivation practices. The higher adoption index $(85.71 \%)$ was recorded in demonstrations plot of Gujarat state whereas lower $(28.57 \%)$ in control plot of Bihar.

This may be attributed to dissimilarity in the soil, fertility status, weather condition and unaware of educate the farmers more about the improved cultivation practices and improved varieties and it means more feasibility of technology disseminations in state.

Technology Disseminations through Demonstrations (TDTD) conducted at farmer's field on 'Improved cultivation practices for onion crop variety Agrifound Dark red (ADR) production in three states viz Bihar, Rajasthan and Gujarat State during kharif 2014-15.

Obtained maximum onion bulb yield with higher monetary returns and $\mathrm{B}: \mathrm{C}$ ratio with higher adoption index and reduction in technology index \% \& extension gap Qtl/ ha in Gujarat State, whereas Obtained minimum onion bulb yield with lower monetary returns and $\mathrm{B}: \mathrm{C}$ ratio, lower adoption index and maximum technology index $\%$ \& maximum extension gap Qtl/ ha in Bihar state. These findings are stated the feasibility of demonstrated technology at farmers field.

It was concluded that crop demonstrations is an effective extension mean to disseminate the proven technology at farmers level and to bridge the extension gap that increase the crop yield, monetary returns and livelihood status of the farming community. These finding are also benefited to planners for making the plans at a planning time means know the adoption index was higher in Gujarat followed by Rajasthan and lower in Bihar state.

\section{References}

Eswaraprasad Y, Manohar Rao M and Vijaya Bhinandana B (1993) Analysis of on farm and level of technology on oilseed and pulse crop in Northern Telgana Zone of Andhra Pradesh, Indian Journal of Agriculture Economics, 48:351-356.

Gupta, R.P.; Singh, R.K.(2010). Area and production. Onion production in India2010, pp 6-9.

Hiremath SM, Nagraju MV.(2010) Evaluation of front line demonstration of onion in Haveri district of Karnataka. Karnataka J. Agric. Sci. 2010;22:1092-1093.

Hiremath SM, Hilli JS. (2012) Performance 
of front line demonstration of onion in Dharwad district of Karnataka. Agric.Update. 2012; 7(3\&4):191-194.

Jeggar KL, Panwar PP, Pareek OP. (2006) Front line demonstration on maize in Bhilwara district of Rajasthan. Current Agric. 2006;30:115- 116.

Kumar A, Kumar R, Yadav VPS, Kumar R. (2010) Impact assessment of front line demonstrations of Bajara in Haryana state. Indian res.J extn.Edu.2010;10(1):105-108.

Lannoy GD. Vegetables crops in Tropical Africa 395-522 in crop production in Tropical Africa, 2001, 1540

Lawanda KE (2005). Onion improvement present status and future trust National symposium on current treds in onion, garlic and seed spices- production, marketing and utilization, held at NRCOG, Rajagurunagar, Pune during 25-27 November, 2005.Pp-1-11.

Mukharjee, N. (2003) Participatory learning and action. Concept Publishing Company, New Delhi, India, 2003, 6365.

Ojha, M.D. and Singh, H. (2013). Evaluation of technology dissemination through demonstration on the yield of Kharif onion. Indian Res. J. Ext. Edu., 13 (1): 129-131.

Pandey, U.B.; Bhonde, S.R. (2002). AgroTechniques. Onion production in India2002, pp 12-15.
Singh R, Soni RL, Singh V, Bugalia HI.(2011) Dissemination of improved production technologies of solanceous vegetables in Banswara district of Rajasthan through frontline demonstrations. Raj. J.Extn.Edu.2011;19:97-100

Singh, H.M. and Singh, S.K. (2018). Evaluation of technology dissemination through demonstration on the yield of Kharif onion bulb production. Asian J. Hort., 13(1): 5-7.

Singh, H. M. and Singh, S. (2018) Impact of TDTD on integrated crop management in Kharif Onion (Allium cepa L.). Bull. Env. Pharmacol. Life Sci., Vol 7 [6]: $37-40$.

Singh, Satyendra and Singh, H M (2018) Impact of Technology Dissemination through Demonstration (TDTD) On yield and Economics of Rabi onion crop in Kurnool district of AP. Adv. Biores., Vol 9 [4] July 2018.94-96.

Straub RW, Emmett B. Pests of monocotyledon crops. In. MC Kinley. R.G. (Editor). Vegetable Crop Pests. Mac Millan Press, U.K, 1992, 213-262.

Teggelli RG, Patil DH, Ananda Naik, Zaheer Ahmad B, Patil M.C.(2015) Impact of frontline demonstration on the yield and economics of Pigeonpea in Kalaburgi district of Karnataka state. Inter.J.Science and Nature. 2015;6(2):224-227

\section{How to cite this article:}

Tiwari. J. K., Divya, H. M. Singh and Garima Tiwari. 2020. Analysis of Yield Gap in Kharif Onion Variety Agri found Dark Red under Demonstrations in Bihar, Rajasthan and Gujarat States of India. Int.J.Curr.Microbiol.App.Sci. 9(03): 2780-2787. doi: https://doi.org/10.20546/ijcmas.2020.903.319 